\title{
ANTHROPOS
}

114.2019: $157-168$

\section{The Politicization of the Immigration Debate in the Netherlands}

\author{
Boat Refugees and the Possible Solution of Border Control
}

\author{
Nina van Haren, Iris Wierstra, and Toon van Meij1
}

\begin{abstract}
This article analyses public discourses in the Netherlands about the arrival of boat refugees in Europe. By comparing three Dutch newspapers with received knowledge about migration in academic literature, we compare and contrast policies advocating border control in order to stop the arrival of boat refugees with scientific evidence about these proposed solutions. We argue that discrepancies exist between policy suggestions and the evidence provided by migration scholars since increased border control generally is argued not to lead to a decline in migrants, but instead to riskier routes and more deaths. Accordingly, we contend that not evidence but a nationalist discourse spreading anxiety influences the political debate. In order to corroborate this argument, we conducted a content analysis of various newspaper reports on boat refugees and their framing of the proposed policy solution of border control. This demonstrates that media are not systematically instigating moral panic as migration scholars would often like us to believe. On the contrary, much diversity is found in newspapers regarding the representation of boat refugees and many similarities may be found in arguments provided by media and scholars. [The Netherlands, immigration, politicization, boat migration, border control, newspapers]
\end{abstract}

Nina van Haren, has been a research student at the Dept. of Anthropology and Development Studies (Radboud University, Nijmegen). - Collaborated with artistic refugees in the Netherlands in order to study their lived experiences in a foreign country. E-mail: nina.vanharen@hotmail.com

Iris Wierstra, has been a research student at the Dept. of Anthropology and Development Studies (Radboud University, Nijmegen), - The subject of her research was how refugees of different religious backgrounds feel supported by their lived religions in the process of homemaking and integration in the Netherlands. E-mail: iriswierstra@outlook.com

Toon van Meijl, Professor and Chair of Cultural Anthropology at the Dept. of Anthropology and Development Studies (Radboud University, Nijmegen). - He has conducted field research in the Pacific since 1982, and has published widely on land issues, indigenous rights, and cultural identity, also in relation to migration. E-mail: T.vanMeijl@ru.nl

On the 19th of April 2015, a boat with 700 refugees sank near the coast of Libya (Peeperkorn $2015 \mathrm{c}$ ). Media called this event the biggest refugee tragedy ever on the Mediterranean Sea. In the spring and summer of 2015, European media, including Dutch news media, paid extensive attention to irregular boat migration from Africa and the Middle East to Europe (J. de Haas 2015). News reports illustrate the political and public debate, which is provoked due to the arrival of boat refugees. A large number of media articles discuss the question how to address the increasing influx of refugees, how to stop the drive to migrate, how to shelter refugees, and, above all, how to end the escalation of shipwrecks and the associated deaths.

The enhanced media attention for boat refugees may be regarded as part of the Dutch immigration debate. In the Netherlands, a shift has occurred from a policy model focusing on multiculturalism, emphasizing the preservation of one's own culture, to an integration policy aiming at assimilation (Penninx 2006). Events such as the September 11 attacks in 2001 and the assassinations of politician Pim Fortuyn and filmmaker Theo van Gogh, known for their critical attitude towards Islam, have transformed the immigration debate in the Netherlands (van der Veer 2006). The current 
support for the populist anti-immigration party of Geert Wilders has continued to develop the public opinion that immigration to the Netherlands could lead to a disruption of society (Penninx 2006).

The Dutch discourse underlying the immigration debate is based on assimilation of migrants in order to maintain and protect the Dutch nation and culture. Fear of the non-Western stranger plays an important role in the dominant discourse in the Netherlands (Lucassen 2005). Besides the fear that immigrants would not contribute socioeconomically, the public is concerned that immigrants might have different, irreconcilable values, compared to those dominant in Western democracies. Therefore, migrants would threaten Dutch national identity (Pugh 2004). Policies are constructed, which are affected by these emotional assumptions instead of empirical evidence (Lucassen en Lucassen 2011). For these reasons, we argue that the Dutch immigration debate is highly politicised.

This means that political interests and emotional connotations are intertwined with political decision-making. This politicization of the debate originates from a nationalist discourse, dominating European societies (Eriksen 2010). "Nationalism is primarily a political principle, which holds that the political and the national unit should be congruent" (Gellner 1983: 1). For Dutch society, this means that the geographical border of the Netherlands overlaps with the imagined border of Dutch ethnicity (Eriksen 2010). Hence, nationalism becomes an emotional force in which a shared culture is an important element (Wimmer and Glick Schiller 2002). This discourse emphasizes a dichotomy between "us" and "them," mentioned by Wimmer and Glick Schiller as the "sacralisation of the national territory" (2002: 309). The increasing fear of the other and the resulting politicized decisions, therefore, can be attributed to this nationalist discourse.

In this article, we examine the implications of the politicization of the immigration debate in the Netherlands by focusing on the case of boat refugees. Our aim is to scrutinize the ways in which the current immigration debate, stirred by the increase of boat refugees entering Europe, is highly politicized. We argue that often negative consequences arise for the people who are the subject of this debate. Information based on scientific research is often ignored or misinterpreted, which affects the decisions made about the lives of migrants. To understand the degree and the implications of the politicization of the immigration debate, we conducted a content analysis of three Dutch newspapers (De Telegraaf, Trouw, and De
Volkskrant) over a period of three months to examine the influence of a nationalist discourse in the content as well as in the framing of these issues regarding migration.

With regard to the content of the newspapers, we identified suggested solutions to tackle the rise of boat refugees and reflected upon these solutions in light of the insights from migration literature. By contrasting the solutions propounded by politicians with the knowledge of scientific migration research, we argue that the decisions made by politicians are not in line with academic findings and, therefore, show influences of politicized thinking. Two main solutions are proposed to stop the increase of boat refugees, but they are not assumed by migration experts to lead to the desired goal of reducing the number of migrants. First, it is suggested to boost development in the countries of origin in order to diminish motivations to migrate (du Pré 2015 a). In the Netherlands, the Minister for Foreign Trade and Development Cooperation of the Labour Party recently allocated 50 million euro to be invested in African economies. When comparing this solution with evidence proposed by migration scholar de Haas (2007), it appears that development aid is counterproductive. Development aid will not stop migration, but it will offer more opportunities to migrate.

A contradiction between policy and evidence, in the second place, is apparent in the proposed policy solution of an intensification of border control to prevent migrants from entering Europe. In this article, we will focus on this proposal to intensify border control, mainly because this solution is being debated in great detail, both in newspapers and in migration literature. Moreover, the solution of border control has already led to a great loss of lives as mentioned above. Based on a thorough comparative analysis of newspaper articles and migration literature, we argue that this strategy of closing borders originates from a politicized instead of a scholarly, evidence-based perspective on migration. Over the last two decades, the European Union sharpened its external borders through measures such as the creation of sea surveillance systems, detection equipment, and the installation of fences to repel migrants (Last and Spijkerboer 2014). The policy is said to be implemented to prevent more boat refugees from drowning at sea. However, it is often argued that the goal of reducing immigration did not succeed, because stricter border control led migrants to take alternative, 
more risky routes to Europe. ${ }^{1}$ These increased controls, therefore, have the opposite effect of a higher death toll of migrants who attempt to cross the Mediterranean Sea. So, it might be argued, that this main solution of sharpening border control is a result of the politicization of the immigration debate, which is based on a nationalist discourse, which entails the fear that European societies will be disrupted by an increasing influx of migrants.

Contributing to the academic literature, that is used in this article, are leading migration scholars such as de Haas (2007, 2008 a, 2008 b), Spijkerboer (2007, 2013), and Carling (2007 a, 2007 b). In several of the articles by these scholars, it is argued that media constitute one of the main sources that cause solutions for the arrival of boat migrants to be based on fear instead of scientific evidence. For that reason, we studied the framing of the case of boat refugees in newspapers as well. Three Dutch newspapers with a diverse background have been investigated, while attention has also been paid to letters to the editor and comments on news reports published on social media. De Haas, among others, argues that news reports represent African migration to the European Union as "an invasion" of migrants, which fuels the anxiety of European citizens and politicians (de Haas 2008 b: 1305). Media would speak of "floods, streams, masses, and even tsunamis against which embankments have to be erected in order to prevent flooding" (van Houtum and Boedeltje 2009: 229). Therefore, "solutions" towards this "problem" of irregular migration by sea are sought in the field of increased border control. ${ }^{2}$ However, we argue for a more nuanced perspective on the framing of newspapers as the cause for anxiety towards boat migrants. While some news items indeed spread the frightening image that is outlined in scholarly reviews, most newspapers are more in line with academic insights. We argue, therefore, that it is necessary to critically analyze the politicized character and implications of the Dutch immigration debate not only in media but also in the representation of media discourses in academia. On the one hand, the solutions offered from the domain of politics are clearly politicized when contrasted with insights from migration scholars. On the other hand, the suggestion that media instigate moral panic and spread xenopho-

1 Spijkerboer (2007; 2013); de Haas (2008 b); van Houtum and Boedeltje (2009).

2 Carling (2007a; 2007b); de Haas (2008 a; 2008b); Pugh (2004); van Houtum and Boedeltje (2009); Spijkerboer (2007; 2013); Last and Spijkerboer (2014). bic ideas is also overstated in some of the articles of these migration scholars. The implications of the political debate could be detrimental for many migrants as migration academics argue that border control is a counterproductive strategy. However, we also call for a more academically underpinned interpretation of the role of the media concerning the spread of anxiety by appreciating the diversity within media concerning the framing of news reports on boat refugees. The media as the main source of the politicized debate could be refuted on the base of our content analysis.

This article will first provide information about our methodological approach. Second, insights into the politicized character of the European migration debate are presented through a comparison of European policy proposals and evidence from migration literature. Third, we examine the framing of news reports about boat migration and border control.

\section{Methods}

In order to analyze the framing of boat refugees in Dutch media and the question to which extent they evoke anxiety, three Dutch newspapers have been investigated: De Volkskrant, Trouw, and De Telegraaf. For a qualitative content analysis, it is important to understand the differences between the newspapers and, therefore, some background information is provided (Silverman 2011).

De Telegraaf is the widest read newspaper in the Netherlands with 455,927 printed editions in 2014 and 105,512 digital readers (NOM, retrieved on 09.06.2015). De Telegraaf is typified as a popular newspaper compared to De Volkskrant and Trouw, which are described as quality newspapers (Bakker en Scholten 2011). "Popular" refers to a considerable focus on entertainment compared to information. The first edition of De Telegraaf was published in 1893. During the Second World War, the newspaper affiliated with Germany, which later caused a publication ban until 1949 (Wolf 2009). De Telegraaf can be considered as a newspaper with a right political tendency and a relatively conservative and populist style. Probably the largest difference with De Volkskrant and Trouw is its readership (Bakker en Scholten 2011). While in De Volkskrant and Trouw highly educated readers, often with an income above average, are relatively overrepresented, the readers of $D e$ Telegraaf represent a cross-section of the Dutch population. 
De Volkskrant also belongs to the three most read newspapers in the Netherlands with 220,091 printed editions in 2014 and 57,691 digital readers (NOM, retrieved on 09.06.2015). This quality newspaper was first published in 1919 and used to be affiliated to Catholic labour unions and the Dutch Labour Party (Hemels 1981). Since the 1960 s, De Volkskrant went through a process of modernization in which it abandoned its Catholic background and became a left-wing oriented, social democratic newspaper (Ybem 2003). De Volkskrant is known for its critical, left-wing political perspective. In recent years, however, the paper is developing into a more high standard paper making room for different perspectives.

Trouw is a smaller newspaper with 88,094 printed editions in 2014 and 12,200 digital users (NOM, retrieved on 09.06.2015). The newspaper emerged as a resistance paper from the German occupation in 1943 during the Second World War (Bakker en Scholten 2011). The paper was strongly affiliated with reformed Christians and the related political parties (Ybema 2003). Since the declining pillarization in the $1950 \mathrm{~s}$, the newspaper reduced its religious ideology. However, its religious and philosophical perspective is still apparent in Trouw. The newspaper is trying to find a balance between attracting a larger public and maintaining a distinct identity that follows its existent readership.

The above-mentioned newspapers are chosen due to their various perspectives and backgrounds. De Volkskrant and Trouw as quality papers and De Telegraaf as a popular newspaper vary in their reports on boat refugees while also the left-winged perspective of De Volkskrant, the right-winged view of De Telegraaf, and the religious-philosophical background of Trouw influence the style and content of the published articles. The keywords: "refugee," "migrant," "immigration," "boat refugee," "asylum," "illegal," "border," "xenophobia," "racism," "discrimination," and "deportation," and derivations thereof, were searched in the online search-engine LexisNexis. For the period from March until May 2015, De Telegraaf contained approximately 170 articles, De Volkskrant 245 articles, and Trouw 210 articles with regard to the subject of this research.

An account of the procedure of this qualitative content analysis of the articles is useful for an understanding of the results. A qualitative content analysis of media reports has been conducted for a period of three months from March until May 2015, a period with much attention to migration issues. We adhered to a grounded theory strategy of coding, using the programme "ATLAS.ti" (Staring 2015). This strategy enabled us to analyze media reports inductively remaining close to the text. It also allowed us to continuously compare and analyze the articles in light of previous articles and insights.

First, an open coding was conducted to distinguish important codes closely related to the empirical material. After this first phase of open coding we made selective codes with regard to subjects that were discussed considerably in the papers. The third phase consisted of the development of theoretical insights by investigating the relations between codes. We have predominantly used memos to write down these theoretical insights.

Furthermore, special attention has been paid to the opinion sections of the newspapers, because these articles go beyond a mere description of the facts and show the various perspectives on boat refugees of the different papers. A distinction was made between opinion articles, columns, and letters to the editor from readers. The newspapers differ in the emphasis on opinion; De Volkskrant has a far larger section of opinion articles and columns than De Telegraaf. However, De Telegraaf receives more comments from readers on social media. Comments of readers on the website of the papers and on Facebook and Twitter are included in the analysis as well. Social media provide places to freely discuss media reports and, therefore, are an interesting source to study the opinion of the readers regarding boat refugees.

The qualitative content analysis of news reports has provided insights into the diverse portrayals of boat refugees and the European political policy suggestions regarding border control. Following a comparative analysis between these policies and scholarly evidence, the politicization of the immigration debate becomes apparent.

\section{Comparative Analysis: Policy and Evidence}

\section{The Policy of Border Control}

We begin our comparative analysis by exploring European decision-making regarding boat migration and the solution of border control as appears in the Dutch newspapers. Later, we shall compare these political decisions made in the European Union and in the Netherlands with scientific evidence about migration.

For a full understanding of the suggested solution of border control, we first need to sketch the problem, which the policy-makers try to tackle. 
Dutch newspapers increasingly give attention to boat migrants who attempt to cross the Mediterranean Sea. Many reports are written about the increase of crossings and the number of migrants who died during their risky endeavor to reach the European continent. Newspapers might give the impression to report on the case as accurately as possible, but it should be stated that there is a lack of reliable data (Last and Spijkerboer 2014).

An increasing number of migrants try to reach Europe by traversing the Mediterranean Sea. In 2013, media reports stated that 42,925 migrants from Africa embarked a vessel to travel to Europe and, in 2014, this number rose to 170,100 (Wagendorp 2015). In the first two months of 2015 an increase of $43 \%$ of migrants who crossed the sea was witnessed compared to those in the same months in 2014 and the expectation is that at the end of 2015, more than half a million may have attempted a crossing (Aantal asielzoekers 2015; van Raaij 2015). This increase of attempts also shows an increase in drowning accidents. 2014 has been depicted as a "dreadful record year when 3419 migrants drowned on the most deadliest crossing in the world" (Verhofstadt 2015). The number of drownings is still increasing: in the first three months of 2015, 486 migrants drowned, which is more than ten times as many as the number of drowned migrants in these months in 2014 (de Fijter $2015 \mathrm{~b}$ ). According to the International Organization of Migration, on the 16th of April 2015, already 900 boat migrants had drowned in the Mediterranean Sea (Venema 2015). Furthermore, in the night of the 18th to the 19th of April, a boat disaster occurred near Lampedusa, where between 700 and 900 migrants perished. ${ }^{3}$

This catastrophe led to an emergency summit in Brussels on the 23rd of April, where heads of state of the EU discussed this issue (van Gessel 2015). The central problem in the summit seems clear, and is in the words of the Italian Prime Minister Renzi to ensure that the Mediterranean Sea is a sea, not a cemetery (Kieskamp 2015). However, the question remains whether the EU is concerned about saving or obstructing migrants (van Raaij 2015). The European leaders constructed a plan of action as a result of the summit in which policies of border control are constructed. A key point of this plan is to triple the financial resources for missions of Frontex, which is the border security agency of the EU (de Boer 2015). Moreover, the heads of state are asked for commitments to send

3 Venema (2015); Italiaanse marine (2015) (De Telegraaf); van Gessel (2015). boats, helicopters, and airplanes for patrolling on sea (Peeperkorn 2015 b). This increased budget of Frontex also intends to expand the search and rescue operations called "Triton" from Italy and "Poseidon" from Greece.

As a second point in the plan of increased border control, the European Union emphasizes the need for detecting human traffickers. These are interpreted as culprits for sending overcrowded boats to Europe, with all its consequences. However, the plan to detect and destroy vessels of the smugglers in Libyan ports and waters by military force needs approval of the Libyan government or a mandate of the United Nations, which has not yet been received. ${ }^{4}$ These political decisions aimed at constructing a "solution" to the problem of boat migration to Europe and the related border deaths. These measures proposed by the European Union correspond with incidents that occurred in the past: in the last two decades Frontex and Eurosur were established, which meant to increase maritime surveillance and control of coastal borders (Last and Spijkerboer 2014; Pugh 2004). Moreover, these measures comprise military action towards the protection of the external borders similar to the recent military plans to destruct boats of smugglers. Therefore, it is useful to reflect on the current policy suggestions in light of received insights in the existing migration literature.

\section{Scientific Evidence about Border Control}

In most European countries, boat migrants are often seen as a dangerous threat to European identity, security, and economic prosperity (Pugh 2004; van Houtum and Boedeltje 2009). A common response to this negative discourse is to exclude migrants to enter Europe in terms of intensified border control. However, the policies implemented in the past, and which the EU proposed again in April 2015, seem unfitting in light of the evidence of an increasing number of lives lost at the Mediterranean Sea. Several scholars, such as de Haas and Spijkerboer, have presented evidence that most of the proposed "solutions" have contradictory results. First, the increased control of the southern European border did not stop migration but led to a change in routes that migrants take (Spijkerboer 2007; 2013; Carling 2007 b). Before the border controls were strengthened, most mi-

4 Europa wil actie in Libië (2015) (De Telegraaf); EU wil marine inzetten tegen mensensmokkel (2015)(Trouw); VN kijken / Plan (2015); Peeperkorn (2015 b). 
grants travelled from the Strait of Gibraltar to European land; nowadays more migrants travel via the Canary Islands. These routes are longer and more dangerous. Moreover, as apparent in the news, migrants are not deterred to cross the Mediterranean Sea, even though these routes are dangerous. So, restricting migrants to come in by intensifying border control will not stop migration, but it will instead force migrants to enter Europe illegally and via more dangerous routes, with a higher risk of drowning (de Haas 2008 b; Spijkerboer 2007; 2013). Therefore, we can expect the number of drownings to rise when the European Union proceeds with its plans to intensify the protection of borders.

Similar to an intensification of border control, tackling the human traffickers with stricter military policies will not stop migration. The policies of stricter border control make it more difficult to enter Europe. This will guide potential migrants into the hands of human traffickers, who will undertake increasingly risky journeys with a possibly higher death toll (de Fijter 2015 a). According to the relief organization Doctors without Borders, human trafficking is growing due to the closed borders of Fort Europe (Kieskamp 2015). Therefore, the goal to counter human traffickers in order to reduce boat migration and associated border deaths is not based on evidence either. Migration is expected to continue, since people will always find (irregular) ways to move (de Haas 2008 a). When there are no legal options to enter Europe, illegal boat migration with the help of smugglers will persist and probably even increase.

\section{Discrepancy between Policy and Evidence: A Nationalist Discourse}

The discrepancy between the inexorable evidence that border control does not reduce migration but enhances riskier routes and related deaths, and the political decisions to nonetheless sharpen the borders, demonstrates the highly politicized character of these decisions. The question remains why politicians implement these policies while there is abundant evidence available that these policies have contradictory effects. One reason could be ascribed to the nationalist discourse that is dominant among a large part of the European population (Wimmer and Glick Schiller 2002; Kristof 1959). This discourse emphasizes the shared culture within the nation and the fear of outsiders. This appears in the growing number of people in European countries who vote for political parties that wish to close external borders (Kieskamp
2015). The anti-immigration party in Great Britain is even against rescue operations on sea, because of its fear for an upsurge of millions of migrants. In countries where large numbers of the population vote for closed borders, politicians need to take into account these desires. Therefore, they cannot make evidence-based decisions, but instead they seem to be making decisions influenced by a nationalist discourse spreading anxiety, which is also evident in the current action plan of the EU.

Moreover, we will provide two other examples of suggested solutions towards the "immigration problem," that involve the nationalist discourse dominating Europe. The influence of public anxiety on migration politics in the first place is illustrated in the response to the EU's plan for an automatic and compulsory distribution of people who are granted asylum (Peeperkorn $2015 \mathrm{a}$ ). This plan was created to ease the burden on countries that are disproportionally affected by the arrival of boat migrants. The quota is based on prosperity, size of the population, the amount of asylum seekers already present in the country, and the percentage of unemployed people. The plan consists of distributing 40,000 asylum seekers across EU member states, mostly from Syria and Eritrea (Oranje 2015). The EU President Donald Tusk urges member states to sacrifice national interests for the greater good (Righton 2015). However, the plan received much criticism from several member states and many do not want to cooperate. That the EU member states do not want to sacrifice their national interests for the greater good is also apparent in the praise that the action plan to save migrants on sea received, whereas caring for those who actually reach Europe does not receive the same kind of acknowledgement (Swerissen 2015; du Pré 2015 b). This discrepancy reveals the anxiety of the citizens of many European countries and their pressure on political decision-making.

The Netherlands also appeared reticent to welcome asylum seekers. This is illustrated, among other things, by the proposal of the Dutch Liberal Party to close all external borders of the EU and to accommodate all refugees in their own region (van de Bles 2015; Hotse Smit en van der Velden 2015). This proposal was immediately depicted as unrealistic and unacceptable by other political parties and refugee organizations, since already $97 \%$ of all refugees finds shelter in surrounding countries and they are legally entitled to apply for asylum in other countries according to the UN Refugee Convention. Besides these objections, migrants will, as mentioned before, always find 
ways to move even though they are obstructed. ${ }^{5}$ The question remains why the Dutch Liberal Party would come up with a plan to close all external borders. To some degree, this might again be traced back to a nationalist discourse. In the Netherlands, the rightwing anti-immigration party of Geert Wilders receives increasing support of the population. With this policy suggestion, the Dutch Liberal Party might aim to attract the growing number of voters with anti-immigration sentiments (Hoedeman en du Pré 2015).

To conclude, in this section we have argued that the suggested solution of border control is a response to a nationalist discourse that is common among a large part of the European population. We have referred to scientific evidence showing unequivocally that increased border control does not lead to a decline in migration but to an increase in riskier routes and border deaths. Hence, the policies of border control are not solutions to the increase of immigration but rather compound the problem.

\section{Content Analysis: The Framing of the Immigration Debate}

Migration scholars such as van Houtum and Boedeltje (2009), de Haas (2008), and Pugh (2004) seem to be inclined to attribute an important role to news media in triggering the politicization of the immigration debate. Media are blamed to portray migrants as a danger for European identity and as an economic threat for Europe. Words as "apocalyptic" and "moral panic" are regularly used to describe the depiction of boat migration in media (de Haas 2008 a; Pugh 2004). Therefore, an analysis of media reports regarding the politicization of the immigration debate is required in order to investigate the degree in which media are indeed instigating moral panic and presenting apocalyptic images of a so-called tsunami of migrants.

\section{Provoking Anxiety in De Telegraaf}

We argue that the role of media in the politicization of the immigration debate is more nuanced than the scholars mentioned above would like us to believe. Just as media in general are not homogeneous, varying opinions about the case of boat migration are published in newspapers. Nonetheless, a dominant opinion in each of the three news-

5 Oonk (2015); Spijkerboer (2007; 2013); de Haas (2008 b). papers is visible and will be presented. We will elaborate on the framing of boat migration in $D e$ Telegraaf, De Volkskrant, and Trouw. To substantiate our argument, we will use the recent suggestion of the Dutch Liberal Party to close all external borders, in order to illustrate the various ways newspapers deal with this politicized policy proposition.

Our analyses of the newspapers show that De Telegraaf comes most close to the way media are portrayed in academic literature. In De Telegraaf, various ways of framing boat refugees as a threat to Europe or the Dutch society may be distinguished. Due to a relatively small opinion section, it seems that De Telegraaf aims to report on news as representing mere facts. However, when analyzing the choices of content and word usage, a frightening perspective appears to be manifest in the representation of the news. First of all, it appears that topics that inflict fear are discussed more extensively in De Telegraaf than in the other newspapers. Much attention is paid to boat accidents and the number of drowned and saved migrants. This offers sensational reports of the idea that migration by boat is a growing phenomenon. Also, much attention is paid to the cruelty of the actions of human traffickers and especially the fear of terrorists entering Europe amidst boat migrants is a widely discussed topic. This indicates an emphasis on topics that provoke anxiety towards the arrival of boat refugees.

Secondly, with regard to language usage, De Telegraaf arouses anxiety towards the influx of boat refugees. Especially human traffickers are portrayed as dangerous and relentless. They are referred to as "the most criminal," "perfidious and heartless criminals," "slavers," "dealers of the death," and "relentless earners," which illustrates the emotional connotations that are evoked by the description of these people. ${ }^{6}$ Sensational language usage is also found with respect to the number of migrants that are entering Europe. Some articles speak of "a mass exodus that preys upon the foundations of our [European] wealth, morals, culture" (Schrader 2015, authors' translation).

Even fiercer reactions can be found in the letters to the editor of De Telegraaf. It often appears that migrants are seen as a threat to the wealth and security of the Netherlands, as the following example of the fear of the disruption of our welfare

6 Als 't water tot aan de lippen staat (De Telegraaf) (2015, authors' translation); van Aalderen (2015, authors' translation); (2015, authors' translation); van Wely (2015, authors' translation). 
system by the arrival of migrants shows: "The number of asylum seekers is doubled and will definitely increase further. For what time does the Netherlands think that they can proceed regarding the growing lack of social facilities?" (Hiskemuller 2015 a, authors' translation). The comments on social media are even more fed with fear. The following statement is a comment on an article published on Facebook in which an IS terrorist is visible on a refugee boat: "Before you know it, we are all dead on the streets. Long live the world!" (IS-terrorist, 2015, authors' translation). That the reactions are more aggressive on social media is also illustrated in another comment in/to the same article: "Put them back on a boat with holes in it" (IS-terrorist 2015, authors' translation).

This last category of remarks on Facebook and Twitter commenting on news reports by De Telegraaf are fairly in line with the representation of media as an important cause of anxiety. The comments consist of words like mass migration and floods that express the fear that this migration trend will impair national wealth and security. It even results in death wishes to the migrants that cross the sea. Hence, these public opinions again indicate the politicization of the immigration debate. However, this is the only source where these kinds of anxious and aggressive remarks are often made. For that reason, too, it may be concluded that the representation of media as instigators of moral panic as argued by migration scholars only appears in the reactions on social media. While the newspaper itself shows light versions of xenophobic expressions, mostly in the choice of content and language use, they do not frame the case of boat refugees as dangerous as, for example, van Houtum and Boedeltje (2009) have argued.

\section{Social and Humane Stance of Trouw and De Volkskrant}

De Volkskrant and Trouw show a remarkably different representation of boat refugees. The framing of boat refugees in these two newspapers is not at all in line with the image of media that is presented by the migration scholars mentioned above. Paradoxically, Trouw and De Volkskrant support the evidence provided by these scholars. Partly due to their background as a paper for respectively Christian parties and the Labour Party, they offer a more social and humane stance. Besides news reports on the number of drowned migrants and recent policy developments, the majori- ty of the articles aim at countering xenophobic ideas. Many articles oppose the idea of migrants as a threat and we have distinguished several ways in which this is manifested in these newspapers.

First, De Volkskrant and Trouw try to humanize the context of refugees by describing personal stories of migrants. These reports recall journeys that migrants had to undertake to come to Europe, explain the situation of a migrant without legal residence papers or show the situation of people in African countries who wish to migrate. ${ }^{7}$ Also stories of European volunteers who provide shelter to refugees or who aim to help boat refugees in Southern Europe are shared (Julen 2015; Bos 2015). With these reports, the image of a refugee as a hostile "other" receives a face with which the readers might sympathize.

A second argument that illustrates that Trouw and De Volkskrant try to oppose the public anxiety of migration is that they regularly publish reports that show the opinion of experts in the field. In this way, they offer a strong alignment with the voice of academic discourse. In both newspapers, migration scholars and other experts in the field show their professional opinion about the solution of border control and other related issues. The above-cited scholars such as de Haas and Spijkerboer find room in these newspapers to spread their ideas (de Fijter 2015a). This illustrates the importance that these two newspapers attach to the voice of experts to counter public stereotypes. They also put the issue of boat refugees in perspective by providing background information that reflects a scholarly view on the situation. A columnist of De Volkskrant, for example, explains with simple statistical figures that Europe, and the Netherlands in particular, are not full and that it is only a small number of migrants that are entering Europe in contrast to the entire population (Smeets 2015).

Another remarkable feature of De Volkskrant and Trouw is their consciousness of the difficulty to represent boat refugees in a nuanced and valid way. They are aware of the role of media framing and the danger of increasing fear towards migrants. Multiple reports are published that reflect on how media in general cope with news regarding migration and on how the papers itself deal with this issue. Trouw, for example, explains in what way they deal with letters to the editor and comments on social media that spread hatred (van Teeffelen 2015). Moreover, opinion articles are published in which the writers dissociate them-

7 Saleh (2015); Zeegers (2015); Broere (2015). 
selves from the aggressive, xenophobic expressions on social media and even with news reports in the De Telegraaf that have a tendency to spread hatred (Middendorp 2015). The articles, which reflect on the way that boat refugees are framed by media predominantly, entail an argument for the preference of a more neutral or humane framing (ten Broeke 2015; Dempsey 2015). Furthermore, mistakes in newspapers and premature assumptions are elaborated upon extensively. Therefore, if inducing anxiety is an inherent part of media, these newspapers do their very best to diminish it.

\section{The Policy Proposition of Closing EU's External Borders}

In this section, we will discuss a particular policy proposition in order to illustrate the different viewpoints of the three newspapers introduced above. We will analyze the proposal of the Dutch Liberal Party to close all external borders of the EU in order to obtain a deeper understanding of the different approaches of the newspapers towards border control. This offers a clear example of our argument that immigration policies not always are based on evidence but are rather resulting from the politicization of immigration. Moreover, the newspapers critically evaluate this proposition, which again illustrates that they do not mainly spread xenophobic ideas but rather portray migration issues in a nuanced way.

The policy suggestion of the Dutch Liberal Party to close all external borders of the EU and to invest the money that is saved in the regions of conflict may be seen as a radical proposition in the current migration debate and, therefore, provoked strong reactions in the newspapers. Many news reports of Trouw and De Volkskrant were in line with academic perspectives on the issue. These reports criticized the policy proposal for its ineffectiveness to stop the arrival of migrants (Tempelman 2015). Other news reports of De Volkskrant and Trouw criticized this policy of strict border control for its inhumane and antisocial character (Mostert 2015). Differences between the two newspapers influenced by differences in the backgrounds of the newspapers can be distinguished with respect to this point. Trouw predominantly emphasized the inhumane character of the policy and the need to show more solidarity with foreigners. This wish for more solidarity, originating in Christian traditions, shows some differences with the perspective of De Volkskrant. De Volkskrant mainly criticizes the Liberal Party for its antisocial character, which reveals its background as a herald for the Labour Party. De Volkskrant, for example, heavily criticizes the way in which the Liberal Party makes no distinction between a refugee, a so-called "fortune hunter" and a terrorist (Shalmashi 2015). Also, the Liberal Party's comparison of a refugee with a Dutch criminal and labelling the arrival of boat refugees an "African problem" received much criticism (von der Dunk 2015). However, also in this case the diversity within the newspaper must be respected, as proponents of the policy suggestion have been heard as well (e. g. Sommer 2015).

The position of De Telegraaf is more in line with the ideas of the Liberal Party. Therefore, the Liberal Party's agreement with the policy proposition of closing the European borders was expected in De Telegraaf. However, De Telegraaf presented the policy proposal in detail, but the reports were critical and often focused on the infeasible character of the policy suggestion and the political interests that underlie the proposal. This critical view substantiates our argument above that the provocation of anxiety in newspapers is not as serious as academic scholars suggest, since even the populist De Telegraaf reflects critically on the feasibility of proposed policies instead of following the popular anti-immigration discourse. In this regard, even De Telegraaf is aware of the politicization of the immigration debate from which this policy proposal originated. In spite of this consciousness, however, a report by De Telegraaf was published, which showed that readers of De Telegraaf had a different opinion about the proposal (Hiskemuller 2015 b). In a section in which readers of De Telegraaf can comment on topical questions, it appeared that $83 \%$ of the readers who commented were in favor of the policy proposal of closing European borders. Moreover, the majority of the readers agreed with the argumentation of the Liberal Party that the arrival of refugees entails risks for national security (91\%) and a disruption of society. This is in sharp contrast with the columns and many letters to the editor of De Volkskrant and Trouw in which this perspective was criticized.

Following the content analysis of the ways in which media frame boat refugees in general, and the policy proposition of the Liberal Party to close EU's borders in particular, we argue for a more nuanced description of media than is represented in migration literature cited above. The quality newspapers Trouw and De Volkskrant, on the one hand, and the popular newspaper De Telegraaf on the other hand, do show significant differences regarding the provocation of anxiety towards migrants. Furthermore, much diversity appears be- 
tween the nuanced and often critical news and columns of the newspapers, on the one hand, and letters to the editor and comments on articles on social media that are more aggressive and fed with fear, on the other hand. Only some comments on social media pages of De Telegraaf reflect the description of the media offered by de Haas and other migration scholars as instigators of moral panic. With respect to the other sources and newspapers, the framing of boat refugees was far more nuanced and much more in line with academic views. Therefore, we refute the assumption of a homogeneous medium that solely emphasizes frightening images of a tsunami of migrants, and we argue for an acknowledgement of the diversity within media.

\section{Discussion and Conclusion}

Our comparative analysis of policy suggestions regarding border control and scientific insights provided by migration scholars shows that a nationalist discourse spreading anxiety about migrants as a threat to European society has far-reaching influences on political debates. Significant discrepancies exist between scientific evidence and policies that are announced to stop the arrival and death of boat refugees. We have argued that these policy propositions are a result of the growing fear of the public towards the arrival of migrants. This fear influences decision-making processes of politicians who aim to conform to the wishes of the public. The rise of right-wing anti-immigration parties in Europe is an example of this preference of the voters. The suggestion of the policy of border control, even in spite of ample scientific evidence that this policy is counterproductive, is a direct result of the politicization of the immigration debate. As we have demonstrated with the discussion of the solution of border control, political ideas are often not in line with academic insights and this can have detrimental effects on the lives of migrants.

We have also criticized the role that several migration scholars have ascribed to media as instigators of moral panic. "The media" is not one homogeneous category that spreads xenophobic images about migrants. Instead, the representation of boat refugees in De Volkskrant and Trouw show many similarities with the arguments in academic debates about migration. De Telegraaf meets to some extent the image of media that is sketched in several articles, especially in its content and language use. However, only on social media the negative framing of media appeared as fierce as discussed by some migration scholars. Therefore, the statement of these academics that the framing of anxiety towards migrants in news media is a main reason for the anti-immigration ideas of the public is difficult to substantiate, based on this analysis. We do agree that media have a role in the rise of nationalist ideas of the public by reporting on the topic extensively. However, the diversity of media must be acknowledged, and the framing of the newspapers must be scrutinized extensively before these fierce statements about media, as main provocateurs of the anxiety towards migrants, can be made.

In sum, we should like to reiterate that our argument suggests that media are not the main source of the politicization of immigration as is frequently stated by the influential migration scholars whom we have cited above. Furthermore, we have demonstrated the flipside of politicizing immigration by providing an analysis of the proposed political solution of border control, which corroborates our point that debates, which are not principally based on scientific evidence, are likely to result in poor political propositions. After all, many migration scholars have demonstrated unequivocally that closed borders do not have the intended effect of a decline in migration, and, indeed, the lack of action to provide shelter for refugees has already resulted in many deaths. Not only for that reason, it is crucial to understand the impact of political ideologies concerning immigration, since often they stand in the way of a more evidencebased strategy to deal with the complicated implications of migration.

\section{Literature}

\section{References Cited}

\section{Bakker, Piet, en Otto Scholten}

2011 Communicatiekaart van Nederland. Overzicht van media en communicatie. Amsterdam: Kluwer.

\section{Carling, Jørgen}

2007 a European Strategies for Reducing "Unwanted" Immigration. Copenhagen: Dansk Institute for Internationale Studier.

2007 b Migration Control and Migrant Fatalities at the Spanish-African Borders. International Migration Review 41/2: 316-343.

Eriksen, Thomas H.

2010 Ethnicity and Nationalism. Anthropological Perspectives. London: Pluto Press.

\section{Gellner, Ernest}

1983 Nations and Nationalism. Oxford: Blackwell. 
Haas, Hein de

2007 Turning the Tide? Why Development Will Not Stop Migration. Development and Change 38/5: 819-841.

2008 a Irregular Migration from West Africa to the Maghreb and the European Union. An Overview of Recent Trends. Geneva: International Organization for Migration.

2008 b The Myth of Invasion. The Inconvenient Realities of African Migration to Europe. Third World Quarterly 29/7: 1305-1322.

Hemels, Joan

1981 De emancipatie van een dagblad. Geschiedenis van De Volkskrant. Baarn: Uitg. Ambo.

Houtum, Henk van, and Freerk Boedeltje

2009 Europe's Shame. Death at the Borders of the EU. Antipode 41/2: 226-230.

\section{Kristof, Ladis}

1959 The Nature of Frontiers and Boundaries. Annals of the Association of American Geographers 49/3: 269-282.

Last, Tamara, and Thomas Spijkerboer

2014 Tracking Deaths in the Mediterranean. In: T. Brian and F. Laczko (eds.), Fatal Journeys. Tracking Lives Lost during Migration; pp. 85-106. Geneva: International Organization for Migration,

Lucassen, Leo

2005 The Immigrant Threat. The Integration of Old and New Migrants in Western Europe since 1850. Urbana: University of Illinois Press.

Lucassen, Leo, en Jan Lucassen

2011 Winnaars en verliezers. Een nuchtere balans van vijfhonderd jaar immigratie. Amsterdam: Bakker.

NOM (Nationaal Onderzoek Multimedia)

2015 Nationaal Onderzoek Multimedia. <http://www.hoi- online.nl/> [06.06. 2015]

Penninx, Rinus

2006 Dutch Immigrant Policies Before and After the Van Gogh Murder. Journal of Internation Migration and Integration / Revue de l'integration et de la migration international 7/22: 241-254.

Pugh, Michael

2004 Drowning Not Waving. Boat People and Humanitarianism at Sea. Journal of Refugee Studies 17/1: 50-69.

\section{Silverman, David}

2011 Interpreting Qualitative Data. Methods for Analyzing Talk, Text, and Interaction. Los Angeles: Sage.

\section{Spijkerboer, Thomas}

2007 The Human Costs of Border Control. European Journal of Migration and Law 9/1: 127-139.

2013 Are European States Accountable for Border Deaths? In: S. S. Juss (ed.), The Ashgate Research Companion to Migration Law, Theory, and Policy; pp. 61-76. Farnham: Ashgate.

Staring, Richard

2015 Over roekeloze speculatie orgiën en de ethiek van het sparen. Gefundeerde theorie op zijn Starings. In: J. Evers (ed.), Kwalitatieve analyse. Kunst én kunde; pp. 285-303. Amsterdam: Boom Lemma.

Veer, Peter van der

2006 Pim Fortuyn, Theo van Gogh, and the Politics of Tolerance in the Netherlands. Public Culture 18/1: 111-124.
Wimmer, Andreas, and Nina Glick Schiller

2002 Methodological Nationalism and beyond. Nation-State Building, Migration, and the Social Sciences. Global Networks 2/4: 301-334.

\section{Wolf, Mariette}

2009 Het geheim van De Telegraaf. Geschiedenis van een krant. Amsterdam: Boom.

\section{Ybema, Sierk B.}

2003 De koers van de krant. Vertogen over identiteit bij Trouw en De Volkskrant. Amsterdam. [Proefschrift, Vrije Universiteit Amsterdam]

\section{Newspapers Cited}

Aalderen, M. van

2015 Gewetenloze mensenhandelaren. De Telegraaf Nieuws van de Dag (22.04.2015): 7.

Aantal asielzoekers

2015 Aantal asielzoekers groeit sterk in EU. Trouw - Wereld (21.03.2015): 15.

Als ' $t$ water tot aan de lippen staat

2015 Als 't water tot aan de lippen staat. De Telegraaf Nieuws-Opinie (25.04.2015): 9.

Bles, W. van de

2015 VVD wil de grenzen sluiten. Trouw - Vandaag (24.03.2015): 5 .

Boer, M. de

2015 Meer geld voor bewaken grenzen. Trouw - Vandaag (24.04.2015): 6 .

Bos, R.

2015 Doen wat Europa achterwege laat. De Volkskrant - Ten eerste (09.04.2015): 3.

Broeke, A. ten

2015 Ik moet toch een mens zijn die ik herken? De Volkskrant-Opinie en debat (24.04.2015): 22.

Broere, $\mathbf{K}$.

2015 In Berekum zie je waarom Europa blijft lokken. De Volkskrant - Ten eerste (25.04.2015): $6 \mathrm{f}$.

Dempsey, J.

2015 Europeanen moet 'comfortzone' delen. De VolkskrantOpinie en debat (24.04.2015): 21.

Dunk, T. von der

2015 Vluchtelingenstroom is ook westers probleem. De Volkskrant-Opinie en debat (02.05.2015): 18.

Europa wil actie in Libië

2015 Europa wil actie in Libië. Mensensmokkel over zee stoppen door bombarderen vaartuigen. De Telegraaf Buitenland (18.05.2015): 12.

EU wil marine inzetten tegen mensensmokkel

2015 EU wil marine inzetten tegen mensensmokkel. Mogherini wil militaire acties op Libische kust. De Telegraaf-Advertentie (15.05.2015): 20.

Fijter, N. de

2015 a Strenger beleid levert juist meer doden op. Trouw Vandaag (13.05.2015): 4.

$2015 \mathrm{~b}$ Tien keer meer drenkelingen. Trouw - Nederland (03.04.2015): 11. 


\section{Gessel, R. van}

2015 "Schepen smokkelaars vernietigen". EU komt met plannen na ramp met vluchtelingen. De Telegraaf - Nieuws van de dag (24.04.2015): 6.

\section{Haas, J. de}

2015 Ingrijpen. De Telegraaf(20.04.2015): 2.

Hiskemuller, $\mathrm{C}$.

2015 a Dit plukkabinet heeft geen boodschap aan belangen burgers. De Telegraaf-Wat u zegt (12.05.2015): 14.

2015 b Vluchtelingenplan omarmd. De Telegraaf - Wat u zegt (24.03.2015): 18

Hoedeman, J., en R. du Pré

2015 VVD sorteert vast voor op rechts. De Volkskrant - Ten eerste (24.03.2015): 4.

Hotse Smit, P., en L. van der Velden

2015 Asielplan VVD. De VVD wil de grenzen van Europa sluiten. De Volkskrant - Opinie en debat (24.03.2015): 21.

IS-terrorist

2015 "IS-terrorist" lachend op vluchtelingenboot. De Telegraaf (12.05.2015): <https://www.facebook.com/telegraaf $>$ [28.05.2015]

Italiaanse marine

2015 Italiaanse marine redt weer duizenden bootvluchtelingen. De Telegraaf-Buitenland (04.05.2015): 13.

Julen, J.

2015 Goedheid alleen is niet genoeg. Trouw - Tijd (25.04.2015): 14-17.

Kieskamp, W.

2015 Vluchtelingenbeleid EU: Geen ommezwaai maar bijstellingen. Trouw - Vandaag (23.04.2015): 6 .

Middendorp, $\mathbf{P}$.

2015 Editie.nl. De Volkskrant - Vonk (25.04.2015): 2.

Mostert, J. P.

2015 Europa moet vluchtelingen opvangen. Trouw - Opinie (24.04.2015): 22.

Oonk, G.

2015 Gesloten grenzen leiden juist tot meer migratie. Trouw - Opinie (18.05.2015): 25.

Oranje, D.

2015 Krenterige opstelling van kabinet. De Volkskrant - Ten eerste (28.05.2015): 15.

Peeperkorn, $M$.

2015 a Brussel wil asielzoekers spreiden over lidstaten. De Volkskrant - Ten eerste (09.05.2015): 2 .

2015 b EU-leiders wacht op spoedtop reeks hete hangijzers. De Volkskrant - Ten eerste (23.04.2015): 5.

2015 c Nieuwe ramp zet EU aan tot actie. De Volkskrant (20.04.2015): 1 .

Plan

2015 Plan voor verspreiding van asielzoekers binnen EU verdient alle steun. Trouw - Opinie (12.05.2015): 17.
Pré, R. du

2015 a Hulp aan Afrika om migratie te stoppen. De Volkskrant (26.05.2015): 1 .

2015 b Zuinig. De Volkskrant - Opinie en debat (16.05.2015): 17.

Raaij, B. van

2015 Wie zijn de smokkelaars die aan hem verdienen? De Volkskrant - Ten eerste (23.04.2015): $4 \mathrm{f}$.

Righton, N.

2015 EU: meer hulp bootvluchtelingen. De Volkskrant - Ten eerste (24.04.2015): 1 .

Saleh, L.

2015 Voor de speedboot moesten we grof geld betalen. De Volkskrant-Opinie en debat (28.04.2015): 20.

\section{Schrader, F.}

2015 Bootvluchtelingen gevolg van verkeerde besluiten. De Telegraaf-Nieuws - Opinie (22.04.2015): 11 .

Shalmashi, B.

2015 Wachten op de toekomst. De Volkskrant - Vonk (28.03.2015): 11 .

Smeets, I.

2015 500.000. De Volkskrant - Sir Edmund (25.04.2015): 43.

\section{Sommer, $\mathbf{M}$.}

2015 Heerlijk die schone handen. De Volkskrant - Opinie en debat (28.03.2015): 17 .

Swerissen, I.

2015 We moeten offers willen brengen voor onze idealen. De Volkskrant - Opinie en debat (16.05.2015): $18 \mathrm{f}$.

Teeffelen, K. Van

2015 Anoniempje wordt steeds zichtbaarder. Trouw - De verdieping (25.04.2015): $4 \mathrm{f}$.

Tempelman, $\mathbf{O}$.

2015 Een boek voor ... . De Volkskrant - Sir Edmund (28.03.2015): 29.

Venema, $S$.

2015 Chaotisch zoeken naar noodoplossingen. De Volkskrant - Ten eerste (16.04.2015): 6.

Verhofstadt, G.

2015 Europa moet zijn hoofd in schaamte buigen. De Volkskrant-Opinie en debat (23.04.2015): 23.

VN kijken

2015 VN kijken naar botenplan EU. Trouw - Vandaag (12.05.2015): 4.

Wagendorp, $B$.

2015 Bootjes. De Volkskrant - Ten eerste (16.04.2015): 2.

Wely, M. van

2015 Gruwelijke reis overleefd: Vluchtelingenkinderen smullen van Italiaanse chocolade. De Telegraaf Buitenland (23.04.2015): 18.

\section{Zeegers, $M$.}

2015 Europa valt Aminoe tegen. De Volkskrant - Vonk (25.04.2015): $6 \mathrm{f}$. 